\title{
Effects of bovine leukemia virus infection on crossbred and purebred dairy cattle productive performance in Brazil
}

\section{Efeito da Infecção pelo vírus da leucose bovina na produção de rebanhos leiteiros mestiços e puros no Brasil}

\author{
Daniela Souza Rajão ${ }^{1}$; Marcos Bryan Heinemann ${ }^{2 *}$; Jenner Karlisson Pimenta Reis ${ }^{3}$; \\ Gissandra Farias Braz'; João Paulo Amaral Haddad; \\ Antonio Candido Cerqueira Leite Ribeiro ${ }^{4}$; Romulo Cerqueira Leite ${ }^{3}$
}

\begin{abstract}
The aim of this study was to evaluate the effects of bovine leukemia virus (BLV) infection on productive performance of dairy cattle in Brazil. A total of 158 blood samples from lactating adult cows, purebred Holstein and crossbred Holstein X Zebu, were analyzed by Agar Gel Immunodifusion Test (AGID) and leukogram. According to AGID and leukogram results, animals were grouped into three categories: seronegative, seropositive without persistent lymphocytosis, and seropositive with persistent lymphocytosis. Milk production data were compared between groups, according to breed. BLV infected females showed lower milk yield than uninfected ones, both purebred and crossbred ones. There was no difference between milk yield of seropositive cows with or without persistent lymphocytosis. These results indicate an association between BLV infection and reduction of milk production, and this study is the first one to show these effects in crossbred Holstein X Zebu cows.
\end{abstract}

Key words: Bovine leukemia virus, milk production, purebred, crossbred, cow

\section{Resumo}

O objetivo desse estudo foi avaliar os efeitos da infecção pelo vírus da leucose bovina (VLB) na produção de vacas leiteiras no Brasil. Foram analisadas 158 amostras de sangue de vacas adultas em lactação puras da raça Holandesa e mestiças Holandês X Zebu. As amostras foram testadas pela Imunodifusão em Gel de Ágar (IDGA) e pelo leucograma. De acordo com os resultados da IDGA e do leucograma, os animais estudados foram agrupados em três categorias: soronegativos, soropositivos sem linfocitose persistente e soropositivos com linfocitose persistente. Os dados de produção leiteira foram comparados entre os grupos, de acordo com a raça. Vacas infectadas com o VLB apresentaram produção de leite inferior que de vacas não infectadas, tanto puras como mestiças. Não houve diferença na produção de leite de vacas positivas com e sem linfocitose persistente. Esses resultados indicam a associação da infecção pelo VLB com a queda na produção de leite, e esse é o primeiro estudo a mostrar tais efeitos em vacas mestiças Holandês X Zebu.

Palavras-chave: Vírus da leucose bovina, produção de leite, pura, mestiça, vaca

\footnotetext{
${ }^{1}$ Drs. em Ciência Animal, Escola de Veterinária, Universidade Federal de Minas Gerais, UFMG, Belo Horizonte, MG, Brasil. E-mail: danirajao@gmail.com; gissabraz@yahoo.com.br

${ }^{2}$ Prof. Dr. do Depto de Medicina Vterinária Preventiva e Saúde Animal, Faculdade de Medicina Veterinária Preventiva, USP, São Paulo, MG, Brasil. E-mail: marcosbryan@usp.br

${ }^{3}$ Profs. Drs. do Dept ${ }^{\circ}$ Medicina Veterinária Preventiva, Escola de Veterinária, UFMG, Belo Horizonte, MG, Brasil. E-mail: jenner@ufmg.br; jphaddad@globo.com; romulocleite@ufmg.br

${ }^{4}$ Dr. em Ciência Animal, Médico Veterinário, Embrapa Gado de Leite, Juiz de Fora, MG, Brasil. E-mail: candido@cnpgl.embrapa.br

* Author for correspondence
} 


\section{Introduction}

Most Zebu (Bos indicus) animals are adapted to the environmental conditions of the tropics and, thereafter, have higher tolerance to heat stress and many tropical diseases (SYRSTAD; RUANE, 1998). Brazilian dairy livestock is constituted mainly of crossbred Holstein X Zebu cattle. This type of crossbreeding leads to a superior performance of crossbreds due to a better adaptation of cattle kept in extensive (loose housing/pasture) systems without significant reduction on milk productivity (MCMANUS et al., 2008; WILSON, 2009).

Enzootic Bovine Leukosis (EBL), caused by bovine leukemia virus (BLV), is a highly disseminated disease in Brazilian dairy herds, with infection rates of up to $56 \%$ (BIRGEL JUNIOR et al., 1995; D'ANGELINO et al., 1998a; MOLNÁR et al., 1999; MATOS; BIRGEL JÚNIOR; BIRGEL, 2005; BARROS FILHO et al., 2010), which is a result of management techniques common to this kind of production (HOPKINS; DIGIACOMO, 1997; FERNANDES et al., 2009).

Although most infected animals are asymptomatic, the disease may cause considerable economic losses. Import restrictions placed on cattle, semen, and embryos generate losses not only to artificial insemination centers and exporters, but also to dairy and meat industry (TRAININ; BRENNER, 2005). Economic losses result from slaughterhouse condemnation of carcasses with lymphoid tumors, treatment of sick and replacement of dead animals (CHI et al., 2002; PELZER, 1997). The losses may be greater due to reduction of milk production and breeding performances, and due to an increase of cull rates of infected animals (RHODES; PELZER; JOHNSON, 2003).

In spite of absence of apparent clinical signs, $30 \%$ of BLV infected animals may develop Persistent Lymphocytosis (PL), a hematological disorder characterized by an increase in circulating B lymphocytes (DEBACQ et al., 2003; GILLET et al., 2007).
The effect of asymptomatic and subclinical BLV infection on milk production has been reported only in purebred Bos taurus animals and some results indicate a decrease in milk production of BLV infected cows (SARGEANT et al., 1997; D'ANGELINO et al., 1998b; OTT; JOHNSON; WELLS, 2003). Because EBL results in economic losses associated with different degrees of breeding and disease manifestation, the purpose of this study was to investigate the association between BLV infection and milk production in Brazilian dairy cattle, according to breed level. This study is the first published report regarding the influence of BLV infection on crossbred animal production.

\section{Material and Methods}

A total of 42 purebred Holstein and 116 crossbred Holstein X Zebu (1/2 to $15 / 16)$ dairy cows were evaluated, chosen randomly using a lottery method without replacement. Sample size was based on the lactating population of the herd, and only healthy lactating cows were included in the study. Therefore, cows should have somatic cell counts (SCC) under $1.0 \times 106 \mathrm{SC} / \mathrm{mL}$ according to Brazilian legislation, negative results for the California Mastitis Test (CMT) throughout the study period, no signs of clinical mastitis, teat or feet lesions prior or during the study period, and negative results for infection with Leptospira interrogans, Mycobacterium bovis, and Brucella abortus by the Microscopic Agglutination test, the Intradermal Tuberculin test, and the Acidified Antigen Agglutination test, respectively. Also, cows did not have any signs of tumor formations or enlarged lymph nodes, indicating absence of lymphosarcoma.

Cows were 48 months or older and were kept in a commercial dairy herd located in Minas Gerais State (Brazil).

All procedures of this study were in accordance with the Ethics Committee of Universidade Federal de Minas Gerais. 
During an 18 months period, blood samples were collected five times for each animal, with a minimum interval of 90 days between collections. Blood was drawn from the coccygeal vein into two sterile disposable vacuum collection tubes, one for serologic analysis and the other one containing sodium citrate for whole blood leukocytes count.

Samples were sent to the laboratory at the Veterinary School on the same day. Serum was harvested from blood samples by centrifugation at 550 x g. Specific antibodies against the envelope viral glycoprotein gp51 were detected using the Agar Gel Immunodiffusion (AGID) test according to Miller and Van Der Maaten (1977).

Blood smears were prepared of freshly collected blood samples and stained by May GrunwaldGiemsa stain (THRALL, 2007). Leukocytes counts and differential blood cell counts were performed by standard hematological techniques. Leukocytes number was measured using a Neubauer Counting Chamber and lymphocyte counts were performed in stained blood smears using an optical microscope according to Thrall (2007).

Based on results from AGID and leukogram counts, animals were grouped into 3 categories: seronegative (SN), seropositive without Persistent Lymphocytosis (SP), or seropositive with Persistent Lymphocytosis (PL). Animals that had negative results for all AGID tests over the study period were classified as seronegative. To be classified as seropositive, animals should have at least one positive AGID result during any period of the study. And to be classified as lymphocytotic, they should present at least two sequential counts increased in three or more standard deviations over the mean lymphocytes value for each breed, with 90 days intervals between them.

The variable analyzed by the model was individual milk yield in one lactation recorded during the studied period and predicted for 305-day twicedaily-milking mature equivalent (305-2X-ME).
Data were obtained electronically from a central database, using a managerial computer program (GEMA, Brazil). Explicative variables were: i) leucosis, according to serologic analyses, which was codified as 0 for seronegative animals, and 1 for seropositive animals; ii) persistent lymphocytosis, according to leukogram count results, which was codified as 0 for animals without persistent lymphocytosis, and 1 for animals with persistent lymphocytosis; iii) breed, which was codified as 0 for crossbred Holstein X Zebu animals, and 1 for purebred Holstein animals; iv) age in months, a continuous variable, and a quadratic function for age was also tested because of the age distribution characteristics; v) days in milk (DIM), in days, a continuous variable.

Percentage of infection for crossbred and purebred females was evaluated by Chi Square test. Mean age from studied groups was tested for equal variances and evaluated by the simple $\mathrm{T}$ test.

Means, 95\% confidence intervals, medians, and interquartile range were calculated. Initially, linear regression models for each variable were created to estimate their effect on milk production. All variables with $p<0.2$ were included in the multivariable regression analysis. The multivariable model was tested manually because of the low number of variables and the ease to evaluate correlations between variables and their effects. The first order interactions pertinent for the studied object were tested.

To check the model validity the hypothesis of equal variances was tested. Furthermore, a normality test was performed for standard residual, as well as the evaluation of residual dispersion related to y values. Variables were transformed when the validity diagnostic test showed any problems in the principle of normality, variance difference between $\mathrm{y}$ and $\mathrm{x}$, and existence of any residual pattern related to y (DOHOO; MARTIN; STRYHN, 2010). 


\section{Results}

A contingency table (Table 1) demonstrates the distribution of serology results by breed, and the numbers of animals in each studied group. A total of 126 animals showed positive results by AGID test. No statistical evidence by the Chi Square test could differentiate infection percentage in purebreds from infection percentage in crossbred females $(\mathrm{p}>0.05)$. Amongst seropositive animals, Persistent Lymphocytosis was observed in 30.6\% of purebred and $35.5 \%$ of crossbred. No statistical evidence by the Chi Square test could differentiate group distribution and Persistent Lymphocytosis occurrence in purebreds from crossbred females ( $p$ $>0.05$ ) (Table 1). Mean ages of the studied groups could not be differentiated by the simple $\mathrm{T}$ test for equal variances $(\mathrm{p}=0.32)$.

Table 1. Studied groups classification after cross-section of Agar Gel Immunodiffusion (AGID) test and leukogram results distributed according to breed.

\begin{tabular}{ccc}
\hline \multicolumn{1}{c}{ Studied Group } & \multicolumn{2}{c}{ Breed } \\
\cline { 2 - 3 } & Purebred & Crossbred \\
\hline Seronegative group & $6(14.3 \%)^{\mathrm{a}}$ & $26(22.4 \%)^{\mathrm{a}}$ \\
Seropositive Group & $36(85.7 \%)^{\mathrm{b}}$ & $90(77.6 \%)^{\mathrm{b}}$ \\
Without Persistent Lymphocytosis & $25(59.5 \%)^{\mathrm{c}}$ & $58(50.0 \%)^{\mathrm{c}}$ \\
With Persistent Lymphocytosis & $11(26.2 \%)^{\mathrm{d}}$ & $32(27.6 \%)^{\mathrm{d}}$ \\
\hline
\end{tabular}

a, b Values with different lowercase letters in the same row differ statistically by Chi Square test $(\mathrm{P}<0.05)$.

Source: Elaboration of the authors.

Data was collected from 158 cows, and descriptive statistic results are shown in Table 2, and in Table 3 are shown results from linear regression for variables with significant effect.

Regression models were constructed and after the liability tests the authors verified that residual were not normally distributed and milk production variance changed according to $\mathrm{x}$ values. Therefore, $\mathrm{y}$ values were transformed logarithmically ( $\mathrm{Ln}$ ). Regression model results are shown in Table 3. After initial analysis two variables were withdrawn from the model. The first one was Persistent Lymphocytosis because this variable did not show significant effect on milk production that could be differentiated statistically $(\mathrm{p}=0.503)$. The other variable excluded from the context was breed, because it is already a well-known factor that interferes with milk yield. Therefore the model only considered the interaction between BLV serological status (positive or negative) and days in milk (DIM). This interaction is displayed in the multivariable model graph (Figure 1), which shows a change in the milk production pattern as the DIM increases, with a tendency of production decrease in negative animals and increase in positive ones. Therefore, it may appear that infected females have higher milk production than non-infected ones, as shown by some variables in Table 2, but this is only apparent due to the multivariable model pattern and not real at 305-2X-ME, when the production was compared. 


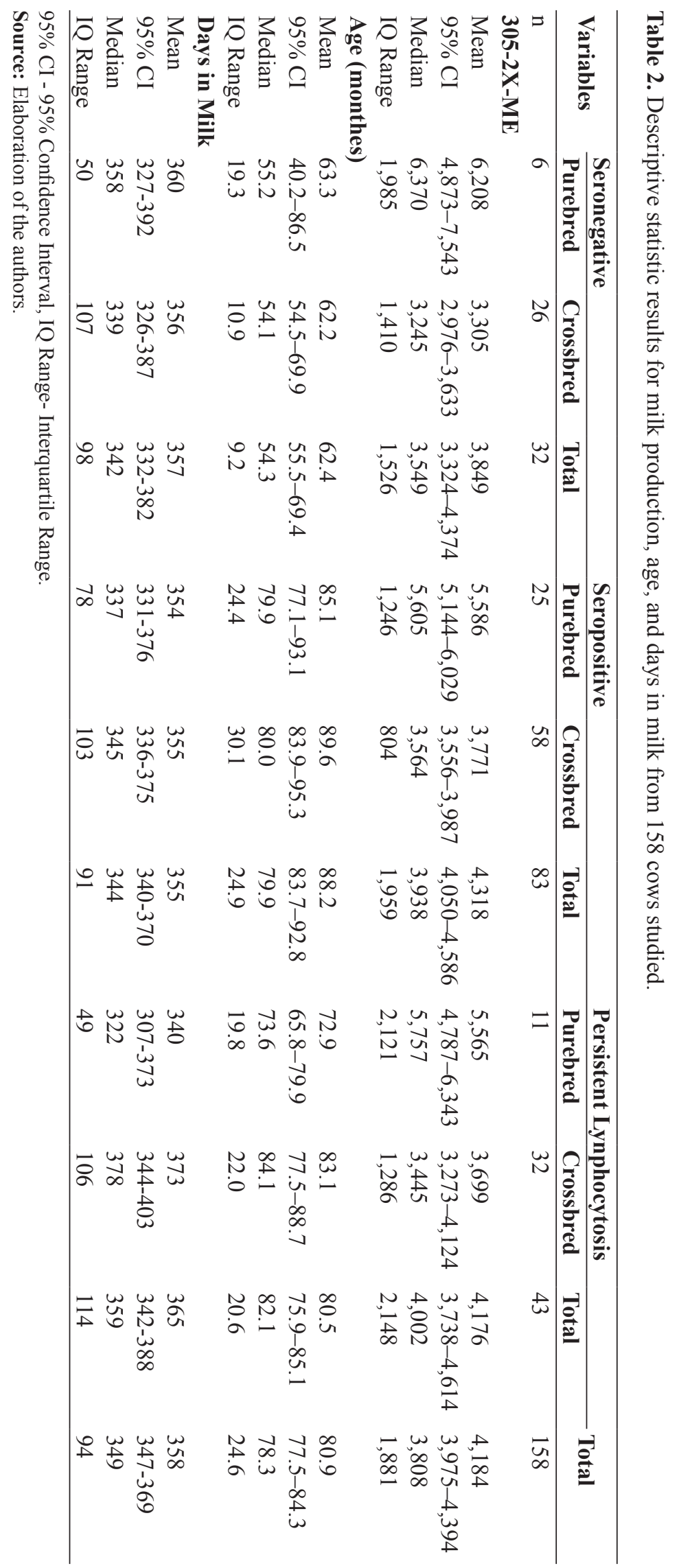


Table 3. Results for Regression modeling using transformed (Ln) milk production according to breed, infection status and days in milk.

\begin{tabular}{lcccc}
\hline \multirow{2}{*}{ Variable } & \multirow{2}{*}{ Coefficient } & \multirow{2}{*}{ P value } & \multicolumn{2}{c}{$\mathbf{9 5 \% \text { Confidence Interval }}$} \\
\cline { 4 - 5 } & & & Inferior border & Superior border \\
\hline Constant & 8.082733 & $\mathrm{p}<0.001$ & 7.648618 & 8.516848 \\
Breed & 0.475513 & $\mathrm{p}<0.001$ & 0.394222 & 0.556805 \\
Leukosis & -0.639813 & 0.010 & -1.121131 & -0.158494 \\
DIM & -0.000408 & 0.494 & -0.001585 & 0.000768 \\
Leukosis X DIM & 0.001821 & 0.007 & 0.000514 & 0.003128 \\
Age & 0.002676 & 0.005 & 0.000815 & 0.004537 \\
\hline
\end{tabular}

DIM - Days in Milk.

Source: Elaboration of the authors.

Figure 1. Graph for multivariable model of milk production in crossbred and purebred cows, positive or negative to Bovine Leukemia Virus (BLV), according to Days in Milk (DIM) period.

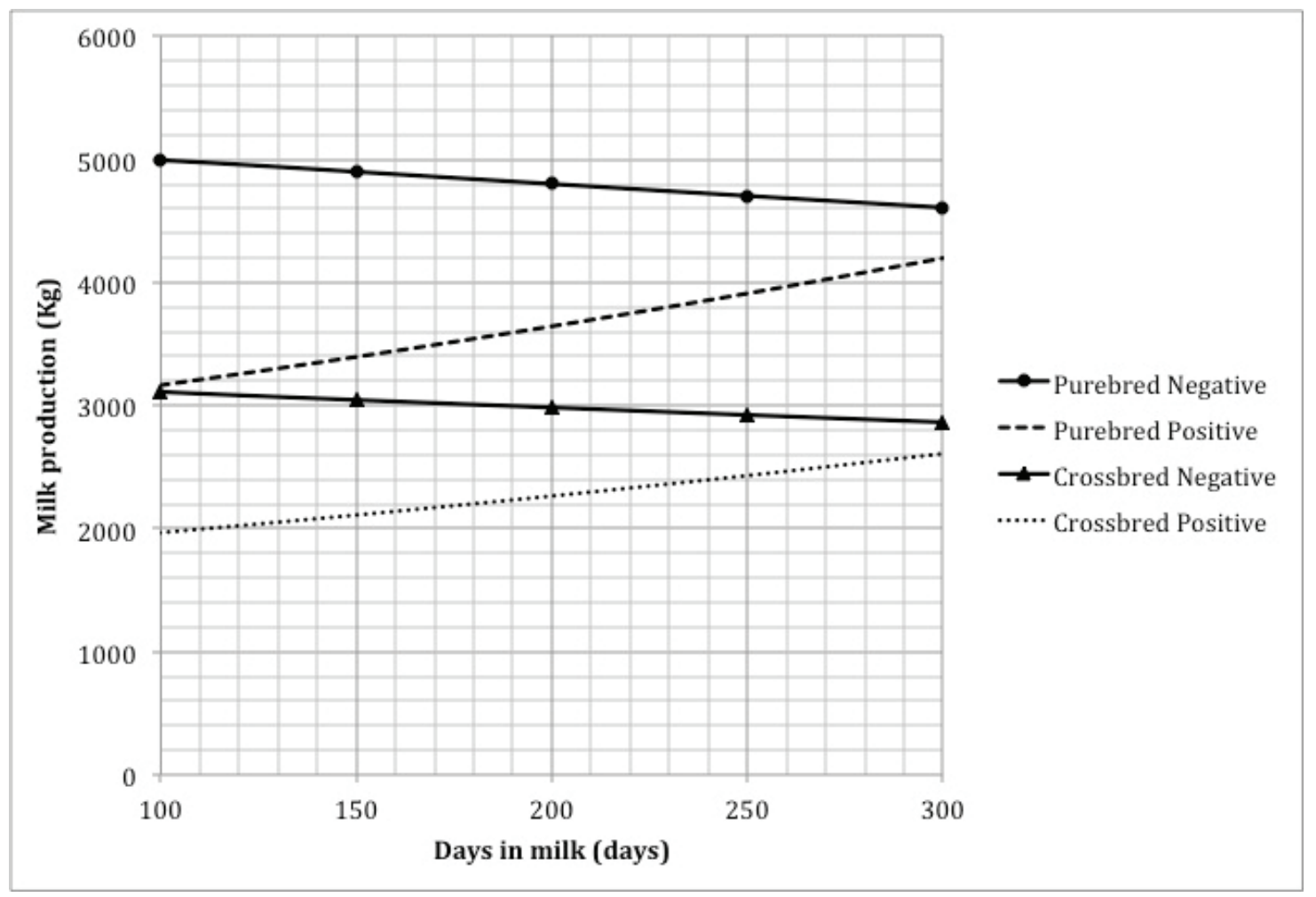

Source: Elaboration of the authors.

\section{Discussion}

This is the first study to address the relation between BLV infection and milk production in crossbred Holstein X Zebu cows.

Seropositivity rate (Table 1) did not differ between purebred and crossbred cows, suggesting that susceptibility to BLV infection may not be breed dependent. The percentage of infected animals with PL was similar to other reports described previously for Enzootic Bovine Leukosis, in which was demonstrated that approximately $30 \%$ of infected animals may develop this hematologic disorder 
(GILLET et al., 2007).

It was demonstrated that both purebred Holstein and crossbred Holstein X zebu cows infected with BLV had lower milk production for adjusted 3052X-ME when compared with non-infected females from the same breed level, with a $9 \%$ reduction per lactation.

Lower milk production of purebred females was also described by D'Angelino et al. (1998b), who showed a loss of $11 \%$ on mean daily milk yield of Holstein BLV-positive cows from São Paulo state, Brazil. Furthermore, other percentages of milk production losses were also described, such as $2.7 \%$ reported by Ott, Johnson and Wells (2003), or $3.5 \%$ found by Brenner et al. (1989). In opposite, some studies have shown that BLV infection has no influence on milk production (KALE et al., 2007; TIWARI et al., 2007) and also in others, BLVpositive cows have even shown an increase in milk production (JACOBS et al., 1991; POLLARI et al., 1992).

However, all previous studies that attempted to demonstrate effects of BLV infection on milk yield used purebred animals, mostly Holstein, instead of crossbred ones (D'ANGELINO et al., 1998b; KALE et al., 2007). Although Bos indicus animals seem to be more resistant to other disease and parasite infection (BOCK et al., 1997; WAMBURA et al., 1998), crossbred Holstein X zebu cows used in this study showed similar susceptibility and effects to BLV infection to those presented by purebred Bos taurus animals.

The negative effect of BLV infection on milk production may be related to direct effects of the virus on mammary glandular cells, as demonstrated by Motton and Buehring (2003). Based on our results and on Brazilian average milk price paid to producers (approximately U\$0.30/Kg) BLV infection could result in losses of more than U\$100/ cow per lactation, which can be a significant economic loss, especially for small producers.

Da et al. (1993) showed that loss on milk production of animals with persistent lymphocytosis was more significant after two years of PL manifestation. In this study performed in a period of 18 months, effects of Persistent Lymphocytosis on milk yield were not observed when infected animals showing PL were compared to non-lymphocytotic ones. Probably these effects are time dependent and take more than two years to be detectable.

Enzootic Bovine Leukosis is highly disseminated on Brazilian livestock, with high prevalence rates in dairy herds. Management practices and frequent animal manipulation used in this kind of production facilitate BLV dissemination and also make introduction of control measures difficult. The true BLV infection economic impact on national milk production is unknown for the government and the dairy industry. This lack of knowledge about the economic harm from EBL may contribute to dissemination of disease because control measures are not done efficiently.

\section{Conclusion}

Results found in this study suggest an association between BLV infection and milk production. This is the first study to actually show that BLV infection has a negative effect on milk production of Crossbred dairy cattle, which predominates in most Brazilian dairy herds. Thus, this study demonstrates that BLV infection can result in considerable economic losses for dairy producers in Brazil.

\section{Acknowledgments}

The authors wish to thank EMBRAPA - Gado de Leite for technical support, and Dr. Marcelo Fernandes Camargos, from Ministry of Agriculture and Food Supply, for technical assistance. This study was supported by Fundação de Amparo à Pesquisa do Estado de Minas Gerais (FAPEMIG) and Conselho Nacional de Desenvolvimento Científico e Tecnológico (CNPq). The authors declare that there are no conflicts of interest. 


\section{References}

BARROS FILHO, I. R.; GUIMARÃES, A. K.; SPONCHIADO, D.; KRÜGER, E. R.; WAMMES, E. V.; OLLHOFF, R. D.; DORNBUSCH, P. T.; BIONDO, A. W. Soroprevalência de anticorpos para o vírus da leucose enzoótica em bovinos criados na região metropolitana de Curitiba, Paraná. Arquivos do Instituto Biológico de São Paulo, São Paulo, v. 77, n. 3, p. 511-515, 2010.

BIRGEL JUNIOR, E. H.; D’ANGELINO, J.; BENESI, F. J.; BIRGEL, E. H. Prevalência da infecção pelo vírus da leucose dos bovinos, em animais da raça Jersey, criados no Estado de São Paulo. Pesquisa Veterinária Brasileira, Seropédica, v. 15, n. 4, p.93-99, 1995.

BOCK, R. E.; DE VOS, A. J.; KINGSTON, T. G.; McLELLAN, D. J. Effect of breed of cattle on innate resistance to infection with Babesia bovis, B. bigemina and Anaplasma marginale. Australian Veterinary Journal, Australian, v. 75, n. 5, p. 337-340, 1997.

BRENNER, J.; Van HAAM, M.; SAVIR, D.; TRAININ, $Z$. The implication of BLV infection in the productivity, reproductivity and survival rate of a dairy cow. Veterinary Immunology and Immunopathology, SA, v. 22, n. 3, p. 299-306, 1989.

CHI, J.; VANLEEUWEN, J. A.; WEERSINK, A.; KEEFE, G. P. Direct production losses and treatment costs from bovine viral diarrhea virus, bovine leucosis virus, Mycobacterium avium subspecies paratuberculosis and Neospora caninum. Preventive Veterinary Medicine, Colorado, v. 55, n. 2, p. 137-153, 2002.

D'ANGELINO, J. L.; GARCIA, M.; BIRGEL, E. H. Epidemiological study of enzootic bovine leukosis in Brazil. Tropical Animal Health and Production, Edinburgh, v. 30, n. 1, p. 13-15, 1998a.

Productive and reprodutive performance in cattle infected with bovine leukosis virus. Journal of Dairy Research, England, v. 65, n. 4, p. 693-695, 1998b.

DA, Y.; SHANKS, R. D.; STEWART, J. A.; LEWIN, H. A. Milk and fat yields decline in bovine leukemia virusinfected Holstein cattle with persistent lymphocytosis. Proceedings of the National Academy of Sciences USA, USA, v. 90, n. 14, p. 6538-6541, 1993.

DEBACQ, C.; ASQUITH, B.; REICHERT, M.; BURNY, A.; KETTMANN, R.; WILLEMS, L. Reduced cell turnover in bovine leukemia virus-infected, persistently lymphocytotic cattle. Journal of Virology, USA, v. 77, n. 24, p. 13073-13083, 2003.

DOHOO, I. R.; MARTIN, W.; STRYHN, H. Veterinary epidemiologic research. 2. ed. Charlottetown: AVC Inc. $2010.865 \mathrm{p}$.
FERNANDES, C. H. C.; MELO, L. E. H.; TENÓRIO, T. G. S.; MENDES, E. I.; FERNANDES, A. C. C.; RAMANLHO, T. R. R.; MOURA SOBRINHO, P. A.; MOTA, R. A. Soroprevalência e fatores de risco da infecção pelo vírus da leucose dos bovinos em rebanhos leiteiros da região norte do Estado do Tocantins, Brasil. Arquivos do Instituto Biológico de São Paulo, São Paulo, v. 76, n. 3, p. 327-334, 2009.

GILLET, N.; FLORINS, A.; BOXUS, M.; BURTEAU, C.; NIGRO, A.; VANDERMEERS, F.; BALON, H.; BOUZAR, A. B.; DEFOICHE, J.; BURNY, A.; REICHERT, M.; KETTMANN, R.; WILLEMS, L. Mechanisms of leukemogenesis induced by bovine leukemia virus: prospects for novel anti-retroviral therapies in human. Retrovirology, England, v. 4, n. 1, p. 1-32, 2007.

HOPKINS, S. G.; DIGIACOMO, R. F. Natural transmission of bovine leukemia virus in dairy and beef cattle. Veterinary Clinics of North America: Food Animal Practice, Philadelphia, v. 13, n. 1, p. 107-128, 1997.

JACOBS, R. M.; HEENEY, J. L.; GODKIN, M. A.; LESLIE, K. E.; TAYLOR, J. A.; DAVIES, C.; VALLI, V. E. Production and related variables in bovine leukaemia virus-infected cows. Veterinary Research Communications, New York, v. 15, n. 6, p. 463-474, 1991.

KALE, M.; BULUT, O.; YAPKIC, O.; GULAY, M. S.; PEHLIVANOGLU, A.; ATA, A.; YAVRU, S. Effects of subclinical bovine leukemia virus infection on some production parameters in a dairy farm in southern Turkey. Journal of South African Veterinary Association, South Africa, v. 78, n. 2, p. 130-132, 2007.

MATOS, P. F.; BIRGEL JÚNIOR, E. H.; BIRGEL, E. H. Leucose enzoótica dos bovinos: prevalência de anticorpos séricos em bovinos criados na Bahia e comparação entre os resultados do teste de ELISA e da imunodifusão em gel de Agar. Brazilian Journal of Veterinary Research and Animal Science, São Paulo, v. 42, n. 3, p. 171-179, 2005.

MCMANUS, C.; TEIXEIRA, R. A.; DIAS, L. T.; LOUVANDINI, H.; OLIVEIRA, E. M. B. Características produtivas e reprodutivas de vacas holandesas e mestiças Holandês $\times$ Gir no Planalto Central, Brazil. Revista Brasileira de Zootecnia, Viçosa, MG, v. 37, n. 5, p. 819823, 2008.

MILLER, J. M.; VAN DER MAATEN, M. J. Use of glycoprotein antigen in the immune diffusion test for bovine leukemia virus antibodies. European Journal of Cancer, Brussels, v. 13, p. 1369-1375, 1977. 
MOLNÁR, E.; MOLNÁR, L.; DIAS, H. T.; SILVA, A. O. A.; VALE, W. G. Ocorrência da leucose enzoótica dos bovinos no Estado do Pará, Brasil. Pesquisa Veterinária Brasileira, Seropédica, v. 19, n. 1, p. 7-11, 1999.

MOTTON, D. D.; BUEHRING, G. C. Bovine leukemia virus alters growth properties and casein synthesis in mammary epithelial cells. Journal of Dairy Science, Savoy, v. 86, n. 9, p. 2826-2838, 2003.

OTT, S. L.; JOHNSON, R.; WELLS, S. J. Association between bovine-leukosis virus seroprevalence and herd-level productivity on US dairy farms. Preventive Veterinary Medicine, Colorado, v. 61, n. 4, p. 249-262, 2003.

PELZER, K. D. Economics of bovine leukemia virus infection. Veterinary Clinics of North America: Food Animal Practice, Philadelphia, v. 13, n. 1, p. 129-141, 1997.

POLLARI, F. L.; WANGSUPHACHART, V. L.; DIGIACOMO, R. F.; EVERMANN, J. F. Effects of bovine leukemia virus infection on production and reproduction in dairy cattle. Canadian Journal of Veterinary Research, Ottawa, v. 56, n. 4, p. 289-295, 1992.

RHODES, J. K.; PELZER, K. D.; JOHNSON, Y. J. Economic implications of bovine leukemia virus infection in mid-Atlantic dairy herds. Journal of American Veterinary Medicine Association, New York, v. 223, n. 3, p. 346-352, 2003.
SARGEANT, J. M.; KELTON, D. F.; MARTIN, S. W.; MANN, E. D. Associations between farm management practices, productivity, and bovine leukemia virus infection in Ontario dairy herds. Preventive Veterinary Medicine, Colorado, v. 31, n. 3-4, p. 211-221, 1997.

SYRSTAD, O.; RUANE, J. Prospects and strategies for genetic improvement of the dairy potential of tropical cattle by selection. Tropical Animal Health and Production, Edinburgh, v. 30, n. 4, p. 257-268, 1998.

THRALL, M. A. Hematologia e bioquímica clínica veterinária. São Paulo: Roca. 2007. 582 p.

TIWARI, A.; VANLEEUWEN, J. A.; DOHOO, I. R.; KEEFE, G. P.; HADDAD, J. P.; TREMBLAY, R.; SCOTT, H. M.; WHITING, T. Production effects of pathogens causing bovine leukosis, bovine viral diarrhea, paratuberculosis, and neosporosis. Journal of Dairy Science, Savoy, v. 90, n. 2, p. 659-669, 2007.

TRAININ, Z.; BRENNER, J. The direct and indirect economic impacts of bovine leukemia virus infection on dairy cattle. Israel Journal of Veterinary Medicine, Israel, v. 60, n. 3, p. 94-105, 2005.

WAMBURA, P. N.; GWAKISA, P. S.; SILAYO, R. S.; RUGAIMUKAMU, E. A. Breed-associated resistance to tick infestation in Bos indicus and their crosses with Bos Taurus. Veterinary Parasitology, Amsterdam, v. 77, n. 1-2, p. 63-70, 1998.

WILSON, R. T. Fit for purpose the right animal in the right place. Tropical Animal Health and Production, Edinburgh, v. 41, n. 7, p. 1081-1090, 2009. 
